University for Business and Technology in Kosovo

UBT Knowledge Center

UBT International Conference

2016 UBT International Conference

Oct 28th, 9:00 AM - Oct 30th, 5:00 PM

\title{
Modeling of Flexural Strength of Fiber Reinforced Concretes Containing Silica Fume or Fly Ash by GEP
}

\author{
Mustafa Saridemir \\ Niğde University, msdemir@nigde.edu.tr \\ Besian Sinani \\ University for Business and Technology, besian.sinani@ubt-uni.net
}

Follow this and additional works at: https://knowledgecenter.ubt-uni.net/conference

Part of the Engineering Commons

\section{Recommended Citation}

Saridemir, Mustafa and Sinani, Besian, "Modeling of Flexural Strength of Fiber Reinforced Concretes Containing Silica Fume or Fly Ash by GEP" (2016). UBT International Conference. 12.

https://knowledgecenter.ubt-uni.net/conference/2016/all-events/12

This Event is brought to you for free and open access by the Publication and Journals at UBT Knowledge Center. It has been accepted for inclusion in UBT International Conference by an authorized administrator of UBT Knowledge Center. For more information, please contact knowledge.center@ubt-uni.net. 


\title{
Modeling of Flexural Strength of Fiber Reinforced Concretes Containing Silica Fume or Fly Ash by GEP
}

\author{
Mustafa Sarıdemir ${ }^{1}$, Besian Sinani ${ }^{2}$ \\ Department of Civil Engineering, Engineering Faculty, Niğde University, 51245 Niğde, \\ Turkey, \\ Department of Civil Engineering, Engineering Faculty, Niğde University, 51245 Niğde \\ Institution /affiliation: UBT College,Faculty of Civil Engineering-Construction and \\ Infrastructure, 10000, Prishtina, Kosovo \\ msdemir@nigde.edu.tr ${ }^{1}$, besian.sinani@ubt-uni.net ${ }^{2}$
}

\begin{abstract}
In this paper, a mathematical equation based on the gene expression programming (GEP) model has been developed to predict the flexural strength $\left(\mathrm{f}_{\mathrm{fs}}\right)$ of steel fiber reinforced concretes (SFRCs) containing silica fume (SF) or fly ash (FA). In order to obtain a mathematical equation of this model, the training, testing and validation sets using the experimental results for 175 specimens produced with 118 different mixtures were gathered from different literatures. The data used in the input variables of GEP model are arranged in a format of eleven input parameters that cover the age of specimen, the amounts of concrete mixtures and the properties of steel fibers. According to these input parameters, the $f_{f s}$ values of SFRCs were predicted in the GEP model. The training, testing and validation results in the model have shown that the model has strong potential to predict the $\mathrm{f}_{\mathrm{fs}}$ values of SFRCs containing SF or FA.
\end{abstract}

Keywords: Fiber reinforced concrete, Silica fume, Fly ash, Flexural strength

\section{Introduction}

The idea of adding steel fiber in concrete to enhance the mechanical properties of concrete is known for many decades. The addition of steel fiber in concrete can enhances many of the mechanical properties such as the ffs, compressive strength, splitting tensile strength, shear strength, fracture toughness, durability, fatigue loading and resistance to impact. The mechanical properties of steel fiber reinforced concretes depend on the aspect ratio (length/diameter), size of fiber, shape of fiber, surface structure of fiber, type of fiber, tensile strength of fiber and the content of fiber [1-3].

Moreover, adding of steel fiber in concrete increase the energy absorption capacity of concrete, and provide to be a more ductile structure of concrete $[4,5]$. The fundamental effect of steel fiber in concrete is revealed after the cement pasta cracking. Steel fibers added in concrete behave as the crack blockers by bridging mechanism, postpone the crack formation, and restrict the crack spread [6,7]. Steel fibers are helpful if a large amount of energy absorption capacity is necessary to decrease brittle failure. $[5,8,9]$. 
Book of Proceedings

International Conference on Civil Engineering, Infrastructure and Environment

Mineral admixtures such as FA, metakaolin, ground granulated blast-furnace slag and SF enhance the mechanical properties, impermeability, workability and durability of concrete when they are employed both the mineral additives and the partial cement replacements [10-12]. Especially, because the SF and FA which are the by-product of industrial plants causes environmental pollution and the cost of storage of their is very high, the employed of SF and FA in concrete mixtures, both in regard to environmental pollution and the positive influence on a country's economy are beyond controversy [13]. The fundamental inclusions of the partial cement replacement by FA in cement matrix are pore filling influence, micro-structure enhancement and better workability of the mixture [14]. Due to an important improvements attained on interface zone of aggregate-cement paste, SF is known to enhance the early as well as the long-term strength and durability of concrete, and produce the high performance concrete and high strength concrete $[13,15]$. SF also plays a significant role on improving of the mechanical strengths of concrete due to having a pozzolonic activity. Filling influence of SF is more dominant than its pozzolonic influence [5]. Also, SF is usually employed together with the super plasticizer or hyper plasticizer to control the workability of concrete $[16,17]$.

The fundamental aim of this study is to predict the ffs values of SFRCs containing SF or FA at the ages of 7, 28, 90 and 365 days by GEP. For this aim, the age of specimen (AS), and cement (C), SF, FA, water (W), maximum aggregate size (Dmax), aggregate (A), superplasticizer (SP), volume of fiber (Vf), length of fiber (Lf) and diameter of fiber (df) used in concrete mixtures were presented to the GEP model as input parameters. The data for training, testing and validation sets of the GEP model were obtained from different literatures [18-25]. The obtained results of the GEP model have been compared by experimental ones to evaluate the software power for predicting the ffs of SFRCs containing SF or FA.

\section{Gene Expression programming}

Gene expression programming (GEP) created first by Ferreira [26] is an extension to genetic algorithms (GA) and genetic programming (GP). GEP develops computer programs of different sizes and shapes encoded in linear chromosomes of fixed length [26,27]. In GEP, five fundamental elements are such as the terminal function sets, fitness function, control parameters, and start-stop condition which must be identified when employing GEP to solve a problem [28]. After the problem is determined for a suitable solution and the fitness function is selected, the algorithm randomly generates a first population of viable chromosomes (individuals) and then transforms each chromosome into an expression tree corresponding to a mathematical expression [29]. Afterwards, the results from mathematical expression are compared with the actual results according to the fitness score of each chromosome. If the predicted results are good enough, the program stops. However, if the predicted results are not good enough, some of the chromosomes are selected using roulette-wheel sampling. The new chromosomes will chance the old ones creating a new generation. This cycle is continued, until the desired fitness score is reached and afterwards, the chromosomes are decoded for the best solution of the problem [29,30]. The chromosomes of GEP are commonly composed of one or more open reading frames. The structure of chromosomes is designed to allow the generation of multiple genes, each encoding a sub-expression tree (Sub-ET). The genes are structurally composed of a head and a tail. The head has symbols that occur both terminals and functions, while the tail has only terminals. Hence, two different alphabets emerge in different regions of a gene. For any problem, the head length " $h$ " and the set of terminals " $n$ " are selected, while the tail length " $t$ " is calculated as a function of $h$ by the Eq. (1) $[26,27]$. 
Modeling of Flexural Strength of Fiber Reinforced Concretes Containing Silica Fume or Fly Ash by GEP

$t=h(n-1)+1$

Consider a gene composed of $\mathrm{F}=\{\mathrm{Q}, \times, /,-,+, \mathrm{a}, \mathrm{b}\}(\mathrm{Q}=\mathrm{Sqrt} / \mathrm{square}$ root $)$. The set of terminals are composed of $\mathrm{T}=\{\mathrm{a}, \mathrm{b}\}$ and in this case, $\mathrm{n}=2$. If the head length is selected as $\mathrm{h}=10$, the tail length is calculated as $t=11$, and the length of the gene is determined as $h+t=10+11=21$. The chromosomes of one such gene (the tail is seen as bold) and the expression tree of this gene is shown in Fig. 1. In addition, the mathematical equation of this gene is given in Fig. 1.

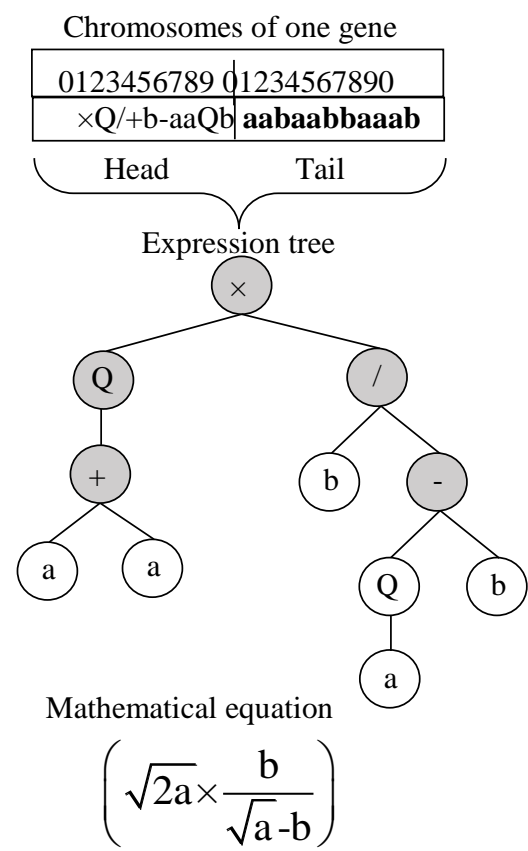

Fig. 1. Expression of GEP gene as ET.

\subsection{Gene Expression Programming Model Structure}

The aim of development of GEP model was to generate the mathematical equation to predict the ffs values of SFRCs containing SF or FA at the ages of 7, 28, 90 and 365 days. For this purpose, a model in the GEP technique was developed. This model is trained and tested with experimental results obtained from different literatures [18-25] to propose the mathematical equation. The number of experimental data obtained from five different experimental studies [18-22] randomly divided for training and testing in this model is 83 and 41, respectively. Besides, the mathematical equation is validated with 51 experimental data obtained from three different experimental studies [23-25], which not employed in training and testing sets of model. For the mathematical equation obtained from the 
Book of Proceedings

International Conference on Civil Engineering, Infrastructure and Environment

GEP model, the first is to determine the fitness function as root mean square error (RMSE). For the predict of ffs, firstly, the fitness of a special program is analyzed by the Eq. (2).

$\operatorname{RMSE}=\sqrt{\frac{1}{\mathrm{n}} \sum_{\mathrm{i}=1}^{\mathrm{n}}\left(\mathrm{t}_{\mathrm{i}}-\mathrm{o}_{\mathrm{i}}\right)^{2}}$

Where " $t$ " is the target value, "o" is the output value and " $n$ " is total number of data. Secondly, the terminal set composes of the independent input parameters, i.e, ffs $=\{$ AS, C, SF, FA, W, Dmax, A, SP, $\mathrm{Vf}, \mathrm{Lf}$ and $\mathrm{df}\}$. For the connection of independent variable, three basic arithmetic operators $(+,-, \times)$ and some basic functions (X2, Inv, Exp, Pow10, 5Rt, Add3, Sub3, Mul3, Cos, Tan,) are used as function set. Thirdly, the length of the head and the number of genes are determined. In this study, after several trials, the numbers of genes and length of head in the best performance for this mathematical model are determined as 7 and 10, respectively. Fourthly, the numbers of genes (Sub-ETs) are linked with addition. Finally, the genetic operators that give rise to variation and their rates are determined. The combinations of all genetic operators and the GEP parameters used in the mathematical equation are given in Table 1.

The terminal set used in the GEP model to predict the ffs from the input parameters are given in the Eq. (3). Furthermore, the mathematical equation defined with the Sub-ETs seen in Fig. 2 are given in the Eq. (4). For the mathematical equation depend on the GEP model seen in the Sub-ETs of Fig. 2, the real parameters are $\mathrm{d} 0=\mathrm{AS}, \mathrm{d} 1=\mathrm{C}, \mathrm{d} 2=\mathrm{SF}, \mathrm{d} 3=\mathrm{FA}, \mathrm{d} 4=\mathrm{W}, \mathrm{d} 5=$ Dmax, $\mathrm{d} 6=\mathrm{A}, \mathrm{d} 7=\mathrm{SP}, \mathrm{d} 8=\mathrm{Vf}, \mathrm{d} 9=\mathrm{Lf}$ and $\mathrm{d} 10=\mathrm{df}$. The constants used in the Sub-ETs of the mathematical equation depend on the GEP model are given in Table 2. The mathematical expressions are $\mathrm{X} 2=\mathrm{x}$ to the power of 2 , Inv=inverse, Exp=exponential, Pow10=10x, 5Rt= quantic root, Add3=addition with 3 inputs, Sub3=subtraction with 3 inputs and Mul3=multiplication with 3 inputs seen in Fig. 2. Considering the above-mentioned input parameters and constants, the final mathematical equation obtained from the GEP model to predict the ffs of SFRCs containing SF or FA at the ages of 7, 28, 90 and 365 days are given in the Eq. (5). 
Modeling of Flexural Strength of Fiber Reinforced Concretes Containing Silica Fume or Fly Ash by GEP
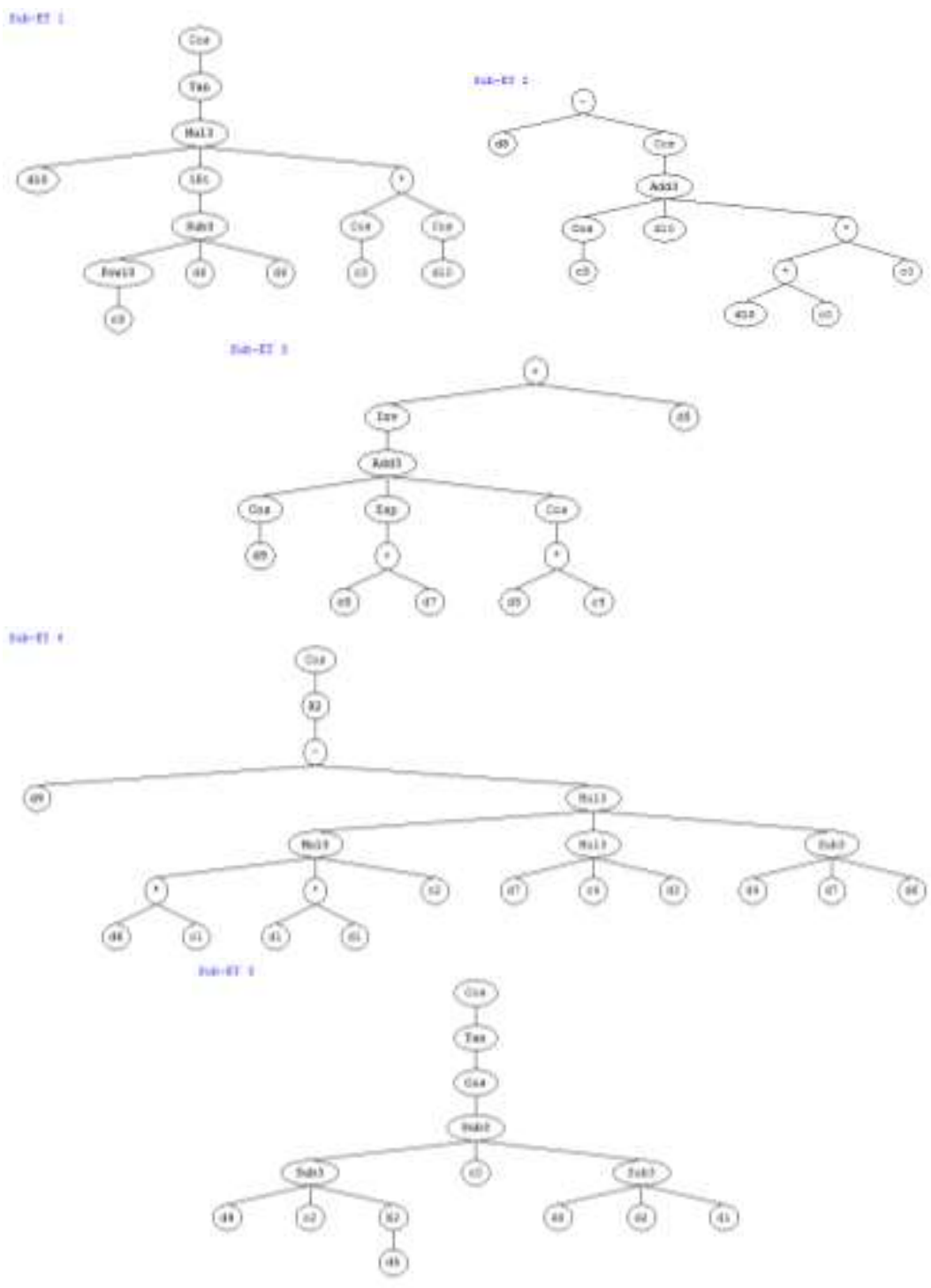
Book of Proceedings

International Conference on Civil Engineering, Infrastructure and Environment

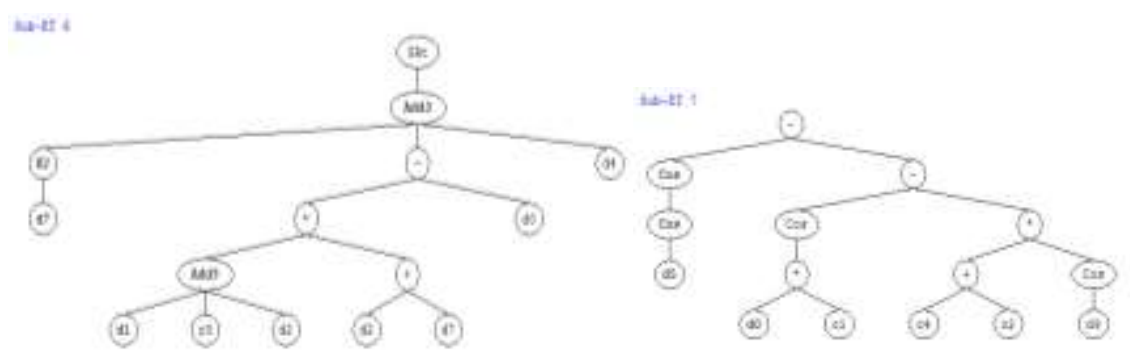

Fig. 2. Expression trees of the mathematical equation depend on GEP.

Table 1. Parameters used in the GEP model.

\begin{tabular}{lc}
\hline Parameter Definitions & GEP \\
\hline Function set &,,$+- \times$, X2, Inv, Exp, Pow10, 5Rt, \\
Add3, Sub3, Mul3, Sin, Cos & 50 \\
Number of chromosomes & 10 \\
Head size & 7 \\
Number of genes & Addition \\
Linking function & 0.00138 \\
Mutation & 0.00546 \\
Inversion & 0.00277 \\
One and two-point recombination & 0.00277 \\
Gene recombination & 0.00277 \\
Gene transposition & 0.0026 \\
Random chromosomes & 4 \\
Constants per gene & \\
\hline
\end{tabular}

Table 2. Constants used in the GEP model.

\begin{tabular}{lccccc}
\hline Constants & $\mathrm{c} 0$ & $\mathrm{c} 1$ & $\mathrm{c} 2$ & $\mathrm{c} 3$ & $\mathrm{c} 4$ \\
\hline Sub-ET 1 & & & & 9.15 & \\
Sub-ET 2 & -7.52 & & & 7.45 & \\
Sub-ET 3 & -2.04 & & & & -4.36 \\
Sub-ET 4 & & -0.25 & 4.75 & & -1.93 \\
Sub-ET 5 & -4.57 & & 6.75 & & \\
Sub-ET 6 & & & & -45.86 & \\
Sub-ET 7 & & 1.76 & 2.76 & & -4.47 \\
\hline
\end{tabular}


Modeling of Flexural Strength of Fiber Reinforced Concretes Containing Silica Fume or Fly Ash by GEP

$$
\begin{aligned}
& \mathrm{f}_{\mathrm{fs}}=f\left(\mathrm{AS}, \mathrm{C}, \mathrm{SF}, \mathrm{FA}, \mathrm{W}, \mathrm{D}_{\max }, \mathrm{A}, \mathrm{SP}, \mathrm{V}_{\mathrm{f}}, \mathrm{L}_{\mathrm{f}}, \mathrm{d}_{\mathrm{f}}\right) \\
& \mathrm{f}_{\mathrm{fs}}=\left[\operatorname{Cos}\left(\operatorname{Tan}\left(\mathrm{d}_{\mathrm{f}} \times 5 \operatorname{Rt}\left(10^{9.15}-2 \mathrm{~A}\right) \times\left(\operatorname{Cos}(9.15) \times \operatorname{Cos}\left(\mathrm{d}_{\mathrm{f}}\right)\right)\right)\right)\right] \\
& +\left[\mathrm{V}_{\mathrm{f}-} \operatorname{Cos}\left(\operatorname{Cos}(7.45)+\mathrm{d}_{\mathrm{f}}+56.55 \mathrm{~d}_{\mathrm{f}}\right)\right] \\
& \left.+\left[1 /\left(\operatorname{Cos}\left(\mathrm{L}_{\mathrm{f}}\right)+\operatorname{Exp}(-2.04+\mathrm{SP})+\operatorname{Cos}\left(-4.36 \mathrm{~V}_{\mathrm{f}}\right)\right)\right)+\mathrm{V}_{\mathrm{f}}\right] \\
& +\left[\operatorname{Cos}\left(\mathrm{L}_{\mathrm{f}}-\left(\left(-1.19 \mathrm{~A} \times \mathrm{AS}^{2}\right) \times(-1.93 \mathrm{SP} \times \mathrm{FA}) \times(\mathrm{W}-\mathrm{SP}-\mathrm{A})\right)\right)^{2}\right] \\
& +\left[\operatorname{Cos}\left(\operatorname{Tan}\left(\operatorname{Cos}\left(\mathrm{Lf}_{\mathrm{f}}-2.18-\mathrm{D}_{\max }{ }^{2}-\mathrm{V}_{\mathrm{f}-\mathrm{SF}} \mathrm{C}\right)\right)\right)\right] \\
& +\left[5 \mathrm{Rt}\left(\mathrm{SP}^{2}+((\mathrm{C}-45.86+\mathrm{SF}) \times(\mathrm{SF}+\mathrm{SP})-\mathrm{AS})+\mathrm{W}\right)\right] \\
& +\left[\operatorname{Cos}\left(\operatorname{Cos}\left(\mathrm{D}_{\max }\right)\right)-\operatorname{Cos}(1.76 \mathrm{AS})+\left(1.71 \times \operatorname{Cos}\left(\mathrm{d}_{\mathrm{f}}\right)\right]\right.
\end{aligned}
$$

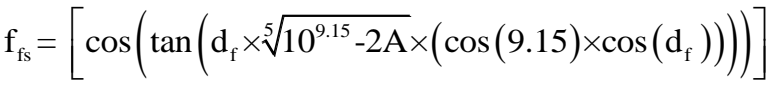

$$
\begin{aligned}
& +\left[\mathrm{V}_{\mathrm{f}}-\operatorname{Cos}\left(\operatorname{Cos}(7.45)+\mathrm{d}_{\mathrm{f}}+56.55 \mathrm{~d}_{\mathrm{f}}\right)\right] \\
& +\left[\left(1 /\left(\operatorname{Cos}\left(\mathrm{L}_{\mathrm{f}}\right)+\mathrm{e}^{(-2.04+\mathrm{SP})}+\operatorname{Cos}\left(-4.36 \mathrm{~V}_{\mathrm{f}}\right)\right)\right)+\mathrm{V}_{\mathrm{f}}\right] \\
& +\left[\operatorname{Cos}\left(\mathrm{L}_{\mathrm{f}}-\left(\left(-1.19 \mathrm{~A} \times \mathrm{AS}^{2}\right) \times(-1.93 \mathrm{SP} \times \mathrm{FA}) \times(\mathrm{W}-\mathrm{SP}-\mathrm{A})\right)\right)^{2}\right] \\
& +\left[\operatorname{Cos}\left(\operatorname{Tan}\left(\operatorname{Cos}\left(\mathrm{L}_{\mathrm{f}}-2 \cdot 18-\mathrm{D}_{\max }^{2}-\mathrm{V}_{\mathrm{f}}-\mathrm{SF}-\mathrm{C}\right)\right)\right)\right] \\
& +\left[\sqrt[5]{\left(\mathrm{SP}^{2}+((\mathrm{C}-45.86+\mathrm{SF}) \times(\mathrm{SF}+\mathrm{SP})-\mathrm{AS})+\mathrm{W}\right)}\right] \\
& +\left[\operatorname{Cos}\left(\operatorname{Cos}\left(D_{\text {max }}\right)\right)-\operatorname{Cos}(1.76 \mathrm{AS})+\left(1.71 \times \operatorname{Cos}\left(\mathrm{d}_{\mathrm{f}}\right)\right)\right]
\end{aligned}
$$

\section{Results and Discussion}

In this paper, the applicability of the mathematical equation obtained from the GEP model was researched to predict the ffs of SFRCs containing SF or FA. The results of mathematical equation obtained from the GEP model to predict the ffs of SFRCs containing SF and FA are able to indicate a very close trend to the experimental results as seen in Fig. 3. It is seen that all of the predicted results for training, testing and validation sets become between $\pm 5 \%$ limits of the best fit line as shown in Fig. 3. As seen in this figure, the predicted results, obtained from training, testing and validation of GEP model, are closer to the experimental results. This situation exhibits that the mathematical equation obtained from the GEP model can be employed for predicting ffs of SFRCs containing SF and FA. 
Book of Proceedings

International Conference on Civil Engineering, Infrastructure and Environment

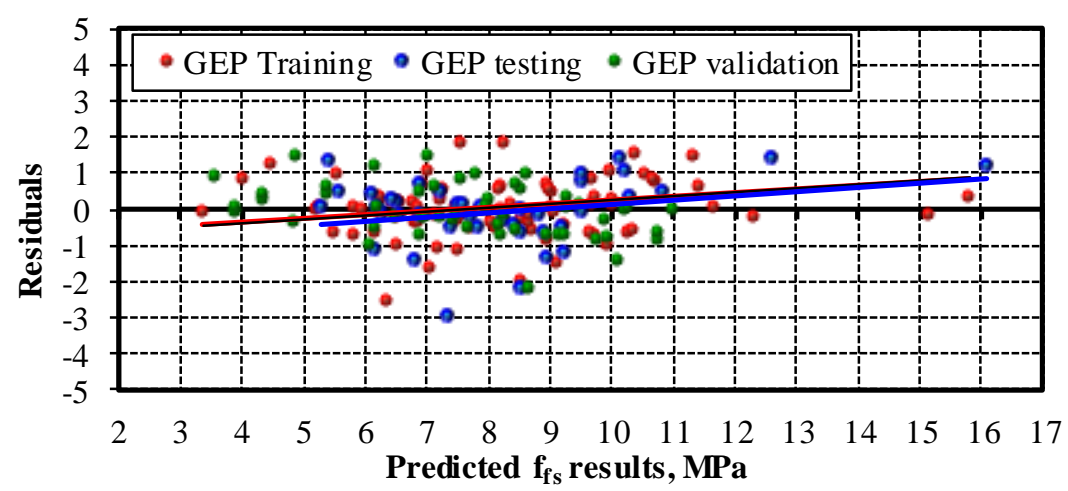

Fig. 3. Scatter of the training, testing and validation sets within $\pm 5 \%$ limits.

The comparisons with the experimental results obtained from different literatures [18-25] and the prediction results of the mathematical equation obtained from the GEP model for the training, testing, and validation sets are given in Fig. 4. The training results in this figure shows that the process of the ffs prediction is learned very well by running GEP model. Besides, this figure exhibits that the testing and validation results attest the correctness in generalization of the mathematical equation proposed with GEP model to predict the ffs.

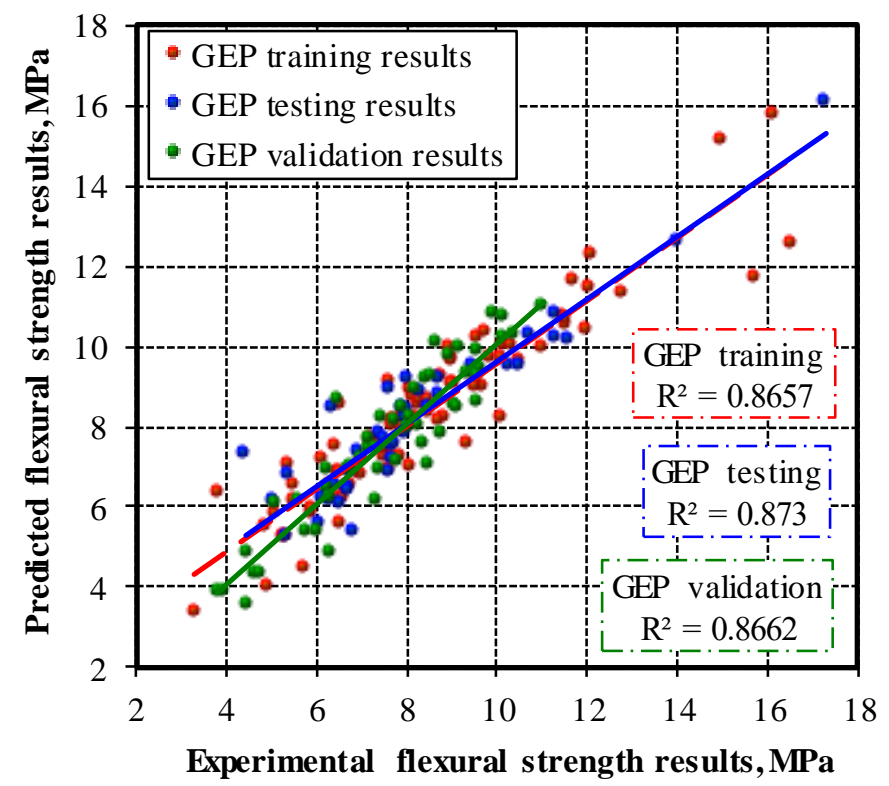

Fig. 4. Predicted ffs versus experimental ffs results for GEP model. 
The results of statistical analyses obtained from the mathematical equation depend on the GEP model and the evaluation of the predictive ability of the mathematical equation were analyzed with some statistical parameters. The root mean square error (RMSE), R-square $\left(\mathrm{R}^{2}\right)$ and mean absolute percentage error (MAPE) given in the Eqs. (2), (6) and (7) were used as statistical verification criteria between the predicted results with experimental results.

$\mathrm{R}^{2}=\frac{\left(\mathrm{n} \sum_{\mathrm{i}=1}^{\mathrm{n}} \mathrm{t}_{\mathrm{i}} \mathrm{o}_{\mathrm{i}}-\sum_{\mathrm{i}=1}^{\mathrm{n}} \mathrm{t}_{\mathrm{i}} \sum_{\mathrm{i}=1}^{\mathrm{n}} \mathrm{o}_{\mathrm{i}}\right)^{2}}{\left(\mathrm{n} \sum_{\mathrm{i}=}^{\mathrm{n}} \mathrm{t}_{\mathrm{i}}^{2}-\left(\sum_{\mathrm{i}=1}^{\mathrm{n}} \mathrm{t}_{\mathrm{i}}\right)^{2}\right)\left(\mathrm{n} \sum_{\mathrm{i}=1}^{\mathrm{n}} \mathrm{o}_{\mathrm{i}}^{2}-\left(\sum_{\mathrm{i}=1}^{\mathrm{n}} \mathrm{o}_{\mathrm{i}}\right)^{2}\right)}$

MAPE $=\frac{1}{n}\left[\frac{\sum_{i=1}^{n}\left|t_{i}-o_{i}\right|}{\sum_{i=1}^{n} t_{i}} \times 100\right]$

Where " $t$ " is the target value, " $o$ " is the output value and " $n$ " is total number of data.

The performance of the mathematical equation obtained from the GEP model is given in Table 3. While the minimum value of RMSE in the validation set is as 0.712 , the maximum value of RMSE in the training set is as 0.985. Similarly, while the minimum value of MAPE in the validation set is as 7.780, the maximum value of MAPE in the testing set is as 8.933 . While the highest value of $\mathrm{R}^{2}$ in the testing set is as 0.873 , the values of $R^{2}$ in the training and validation sets are equal as 0.873 . All of the statistical parameters results in Table 3 reveal that the mathematical equation obtained from the GEP model are suitable and can predict the $f_{\mathrm{fs}}$ of SFRCs containing SF or FA very close to the experimental results.

Table 3. Results of statistical parameters.

\begin{tabular}{cccc}
\hline \multirow{2}{*}{$\begin{array}{c}\text { Statistical } \\
\text { parameters }\end{array}$} & \multicolumn{3}{c}{ GEP } \\
\cline { 2 - 4 } & Training & Testing & Validation \\
\hline RMSE & 0.985 & 0.904 & 0.712 \\
R $^{2}$ & 0.866 & 0.873 & 0.866 \\
MAPE & 8.277 & 8.933 & 7.780 \\
\hline
\end{tabular}

\section{Conclusions}

This paper reports an efficient approach for a mathematical equation of the flexural strength values of SFRCs containing SF or FA using GEP. The mathematical equation to predict the $\mathrm{f}_{\mathrm{fs}}$ of SFRCs containing SF or FA without web reinforcement has been obtained by GEP technique. The experimental results, the age of specimen, the amounts of concrete mixtures and the properties of steel 
Book of Proceedings

International Conference on Civil Engineering, Infrastructure and Environment

fibers obtained from different literatures are used to build and validate the model. All of the results obtained from the mathematical equation show good agreement with experimental results. The statistical parameter values of RMSE $\mathrm{R}^{2}$ and MAPE have shown this situation. The mathematical equation obtained from the GEP model is so simple that they can be employed by anyone not enforcedly being familiar with GEP technique. The mathematical equation obtained from the GEP model also gives a convenient way for the prediction of $\mathrm{f}_{\mathrm{fs}}$ values of SFRCs containing SF or FA to obtain accurate results, and encourages the employ of GEP technique in the other ways of civil engineering studies.

\section{References}

1. Fanella, D.A., Naaman, A.: Stress-Strain Properties of Fiber Reinforced Mortar in Compression. ACI J. 82(4) (1985) 475-83

2. Holschemacher, K., Mueller, T., Ribakov, Y.: Effect of Steel Fibres on Mechanical Properties of High-Strength Concrete. Mater. Design 31 (2010) 2604-15

3. Nili, M., Afroughsabet, V.: Combined Effect of Silica Fume and Steel Fibers on the Impact Resistance and Mechanical Properties of Concrete. Int. J. Impact Eng. 37 (2010) 879-86

4. Hsu, L.S., Hsu, C.T.T.: Complete Stress-Strain Behavior of High-Strength Concrete Under Compression. Mag. Concrete Res. 46(169) (1994) 301-12

5. Köksal, F., Altun, F., Yiğit, İ., Şahin, Y.: Combined Effect of Silica Fume and Steel Fiber on the Mechanical Properties of High Strength Concretes. Constr. Build. Mater. 22 (2008) 1874-80

6. Banthia, N., Trottier, J.F.: Concrete Reinforced with Deformed Steel Fibres. Part II: Toughness Characterization. ACI Mater. J. 2 (1995) 146-54

7. Kurihara, N., Kunieda, M., Kamada, T., Uchida, Y., Rokugo, K.: Tension Softening Diagrams and Evaluation of Properties of Steel Fibre Reinforced Concrete. J. Eng. Fract. Mech. 65 (2000) 235-45

8. Gopalaratnam, V.S., Shah, S.P., Batson, G.B., Criswell, M.E., Ramaksishran, V., Wecharatara, M.: Fracture Toughness of Fiber Reinforced Concrete. ACI Mater. J. 88(4) (1991) 339-53

9. Shah, S.P., Rangan, B.V.: Fiber Reinforced Concrete Properties. ACI Mater. J. 68(2) (1971) 126-35

10. Malhotra, V.M., Mehta, P.K.: Pozzolanic and Cementitious Materials. Advances in Concrete Technology, Gordon and Breach, London, 1996.

11. Hassan, K.E., Cabrera, J.G., Maliehe, R.S.: The Effect of Mineral Admixtures on the Properties of High-Performance Concrete. Cem. Concr. Compos. 22 (2000) 267- 71

12. Oner, T.A., Akyuz, S., Yildiz, R.: An Experimental Study on Strength Development of Concrete Containing Fly Ash and Optimum Usage of Fly Ash in Concrete. Cem. Concr. Res. 35 (2005) $1165-1171$

13. Zhang, P., Li, Q.-f.: Effect of Polypropylene Fiber on Durability of Concrete Composite Containing Fly Ash and Silica Fume. Comp.: Part B. 45 (2013) 1587-94

14. Kondraivendhan, B., Bhattacharjee, B.: Flow Behavior and Strength for Fly Ash Blended Cement Paste and Mortar. Int. J. Sust. Built Env. 4 (2015) 270-7 
Modeling of Flexural Strength of Fiber Reinforced Concretes Containing Silica Fume or Fly Ash by GEP

15. Lee, S.T., Lee, S.H.: Mechanical Properties and Durability of Cement Concrete Incorporating Silica Fume. J. Korean Ceram. Soc. 47(5) (2010) 412-8

16. Hassan, K.E., Cabrera, J.G., Maliehe, R.S.: The Effect of Mineral Admixtures on the Properties of High-Performance Concrete. Cem. Concr. Compos. 22(4) (2000) 267-71

17. Kaikea, A., Achoura, D., Duplan, F., Rizzuti, L.: Effect of Mineral Admixtures and Steel Fiber Volume Contents on the Behavior of High Performance Fiber Reinforced Concrete. Mater. Design 63 (2014) 493-9

18. Sahin, Y. Koksal, F.: The Influences of Matrix and Steel Fiber Tensile Strengths on the Fracture Energy of High-Strength Concrete. Constr. Build. Mater. 25 (2011) 1801-1806

19. Atiş, C.D., Karahan, O.: Properties of Steel Fiber Reinforced Fly Ash Concrete. Constr. Build. Mater. 23 (2009) 392-399

20. Köksal, F., Altun, F., Yiğit, İ., Şahin, Y.: Combined Effect of Silica Fume and Steel Fiber on the Mechanical Properties of High Strength Concretes. Constr. Build. Mater. 22 (2008) 1874-1880.

21. Niu, D., Jiang, L., Bai, M., Miao, Y.: Study of The Performance of Steel Fiber Reinforced Concrete to Water and Salt Freezing Condition. Mater. Design 44 (2013) 267-273.

22. AL-Ameeri A., The Effect of Steel Fiber on Some Mechanical Properties of Self Compacting Concrete. American J. Civil Eng. 1(3)(2013)102-110.

23. Nili, M., Afroughsabet, V.: Combined Effect of Silica Fume and Steel Fibers on the Impact Resistance and Mechanical Properties of Concrete. Inter. J. Impact Eng. 37 (2010) 879-886.

24. Soulioti, D.V.; Barkoula, N.M.; Paipetis, A.;Matikas, T.E.: Effects of Fiber Geometry and Volume Fraction on the Flexural Behaviour of Steel-Fiber Reinforced Concrete. Strain (2011).

25. Ramadoss, P., Nagamani, K.: Tensile Strength and Durability Characteristics of HighPerformance Fiber Reinforced Concrete. Arab. J. Sci. Eng. 33(2B)(2008)307-319

26. Ferreira, C.: Gene Expression Programming: A New Adaptive Algorithm for Solving Problems. Complex Syst. 13(2) (2001) 87-129

27. Ferreira, C.: Genetic Representation and Genetic Neutrality in Gene Expression Programming. Adv. Complex Syst. 5(4) (2002) 389-408

28. Çanakcı, H., Baykasoğlu, A., Güllü, H.: Prediction of Compressive and Tensile Strength of Gaziantep Basalts Via Neural Networks and Gene Expression Programming. Neural Comput. Appl. 18 (2009)1031-1041

29. Kayadelen, C., Gunaydın, O., Fener, M., Demir, A., Ozvan, A.: Modeling of the angle of shearing resistance of soils using soft computing systems. Expert Syst. Appl. 36 (2009) 11814-6.

30. Teodorescu, L., Sherwood, D.: High Energy Physics Event Selection with Gene Expression Programming. Comp. Phys. Commun. 178 (2008) 409-419 